\title{
The Feedback Effect of Rare Earth Development Policy on Economy and Society
}

\author{
MA Jie ${ }^{1, *}$, LI Menglian ${ }^{2, * *}$ \\ ${ }^{1}$ Center for Strategic Studies on Resources and Environment, East China University of Technology, 330013, Nanchang, Jiangxi, China; \\ ${ }^{2}$ School of Economics and Management, East China University of Technology, 330013, Nanchang, Jiangxi, China;
}

\begin{abstract}
China is rich in rare earths (RE). However, the exploitation of rare earths not only promoted the social and economic development, but also produced negative environmental externalities, so the relevant departments issued policies and regulations to carry out pollution control work. This paper made a macroanalysis of China firstly. And then this paper took Jiangxi province as the main research area, which compared with Inner Mongolia, Guangdong, Sichuan and Fujian. This paper used the method of non-radial SBM to measure policy execution efficiency. Based on calculating the social and economic development indicator, economic development and social development indicator, this paper explored the feedback correlation of policy execution efficiency and the development of society and economy by grey relational analysis. The results showed that China reduced its dependence on rare earth resources. However, the efficiency of policy implementation needs to be improved. Effective implementation of rare earth industry policy has a feedback effect on social and economic development. From the perspective of case analysis, the implementation efficiency of vegetation destruction policy in Jiangxi province is higher than that of air pollution policy. The overall policy implementation efficiency of Jiangxi province has a strong feedback effect on the overall level of social and economic development, among which the air pollution and water pollution policy implementation efficiency has a relatively obvious feedback effect on social and economic development.
\end{abstract}

\section{Introduction}

Rare earth is known as "industrial gold" and is widely used in many fields such as military and national economy. Rare earths have long been regarded as strategic resources because of their interaction with corporate and government interventions[1]. On a global scale, China is the country with the largest reserve of rare earth resources. Rare earth elements (REE) in China account for $85 \%$ of the global supply [2]. According to data released in January 2017, the total rare earth reserve across the globe is about 120 million tons (REO), while 44 million tons (REO) of rare earth reserve are distributed in China are (REO), accounting for about $37 \%$ of the world's total [3]. Jiangxi Province is the main resource source for ionic middle and heavy rare earth in southern China. According to relevant announcements of the Ministry of Land and Resources, there are three exploration rights and 89 mining rights for rare earth in Jiangxi Province. The reserve of rare earth resources in Jiangxi Province accounts for $35 \%$ of the total, while the proportion of Guangdong, Hunan, Yunnan, Guangxi, and Fujian Province is $33 \%, 4 \%, 2 \%, 11 \%$ and $15 \%$ respectively.

The rare earth industry in China has achieved rapid development. However, at the same time, due to extensive mining and the backward smelting process in some regions, the resources are excessively consumed and the ecological environment is seriously polluted, which is mainly reflected in ecological vegetation destruction, soil erosion, soil pollution and acidification and excessive discharge of three wastes. To protect and rationally develop rare earth resources, the Ministry of Land and Resources and the relevant departments of Jiangxi Province have promulgated a series of policies and regulations to strictly control the total amount of rare earth mining and carry out environmental restoration and management. A series of guiding documents such as the Outline of the Thirteenth Five-Year Plan for National Economic and Social Development and Made in China 2025 have defined the direction for the regulation and governance of the rare earth industry. In 2017, the funds involved in the geological environment management of abandoned rare earth mines reached up to 286 million yuan among the basic central awards and subsidies fund obtained by Ganzhou and the area of abandoned rare earth mine was 9.61 square kilometers [4]. It can be seen that the policy promulgation is of certain effects on the management of rare earth resources and environmental protection. However, it deserves further exploration to specifically measure the effect of policies and evaluate the effect of the implementation of policies on social and economic development.

\footnotetext{
*Email: jma@ecut.edu.cn

***Email:1m195925@163.com
} 


\section{Literature Review}

Rare earth is an important strategic reserve resource of our country and has an irreplaceable position in the whole world. For a long time, scholars have emphasized the research in cutting-edge technology and application related to rare earth development. In recent years, three major research topics have emerged in the field of rare earth science, namely, separation and extraction technology [5-7], recycling technology [8-11] and alternative technology [12]. Metals and minerals account for a relatively small proportion of world industrial output, but their supply is critical to the value-added activities of the economy[13].With the development of rare earth industry, many scholars have shifted their researches on rare earth to the economic field and begun to pay attention to the sustainable development of rare earth industry[1415], rare earth export trade and policies [16-18] and regulations [19-20]. There is a certain proportion of illegal market in China, which neglects the damage to the ecological environment caused by rare earth exploitation and produces obvious negative externalities [21]. In view of the current development situation of rare earth industry in China, Ni et al (2010) proposed corresponding protective development strategies [22]. Fang et al. (2014) believed that the rare earth product in China is still in the low-end of the global rare earth industry chain, and analyzed the opportunities and challenges of China's rare earth industry from the perspective of the effect of policy implementation[23]. Due to practical interests, the lowcarbon path of rare earth industry had been hindered. In the face of such difficulties, Liu and Tan (2014) indicated that the legal and regulatory system should be improved and appropriate policy orientation should be formed to achieve the low carbon development of rare earth industry[24]. These studies have carried out statistics and analysis on the historical data of rare earth industry and discovered that the consumption and trade of rare earth resources are severely challenged, which is of great practical significance for the sustainable and stable development of rare earth industry.

To more intuitively reflect the damage to the environment caused by rare earth development, some scholars have adopted the empirical research method to carry out quantitative researches on the negative externalities and industrial policies of rare earth development and analyze the relationship between rare earth development and social, economic development. Yang and Cai (2015) studied the situation of China's supply of rare earth and world demand through regression analysis and pointed out the factors that affect the sustainable development of rare earth industry. They believed that the ecological environment value should be considered in the value of rare earth [25]. There are different policy plans at different time stages. Therefore, Wang(2015) introduced the dummy variables of time and policy and used time series regression models to analyze the policy effect of the rare earth industry at different stages [26]. How to verify whether the policies promulgated in all aspects are reasonable and effective deserves further consideration. Based on China's export data of rare earth products, He and Feng (2017) examined the effect of export policies of rare earth products, such as eliminating export tax rebate, raising export tariffs and controlling the export of primary products through the regression analysis under the perspective of the export structure of enterprises' rare earth products[27].

In order to further explore the relationship between economic development and the implementation of rare earth policies, Amsden (1989) took South Korea as an example and concluded that the effective implementation of policies could promote national economic growth by exploring the positive effect of national policy implementation. Thus, it can be deduced that the effective implementation of rare earth industrial policies has a feedback effect on economic development [28]; Sun (2016) indicated that the effect of policy implementation was related to the level of marketization. When the level of marketization exceeds a certain limit, the positive effect of policies will have a magnifying effect. That is, there is a clear positive correlation between economic and social development and industrial policies under the effect of marketization [29].

Based on the above discussions, it can be found that: (1) most studies focus on macro-national perspectives and the research on specific regions is insufficient; (2) due to the limitation of data collection, qualitative research is still the mainstream method adopted by most scholars, and quantitative research is relatively lacking; (3) the research will involve the negative externalities of environmental development caused by rare earth development, but the analysis of the subsequent impact of negative environmental externalities is insufficient; (4) the promulgation of rare earth policies may have a positive effect on the development of social economy and it needs to be tested combined with the actual situation. Based on the above judgments, this paper takes Jiangxi Province as the main research area, compares it with four other regions, namely Inner Mongolia, Guangdong, Sichuan and Fujian, and uses the quantitative analysis method to explore the correlation between the policy effect of negative environmental externalities caused by rare earth development and the policy feedback.

\section{Macro Analysis}

At present, the production structure of rare earth minerals in China is mainly divided into three types: mixed rare earths, bastnaesite and ion- type rare earths. Since 1990, mixed rare earth minerals have become the main source of rare earth products in China, reaching a maximum of 69,000 tons in 2007, while the output of bastnaesite reached a minimum of 6,800 tons in that year. From 1990 to 2006, the production of ion-type rare earthls increased year by year, and it continued to decline after reaching a maximum output of 45,129 tons in 2006. 


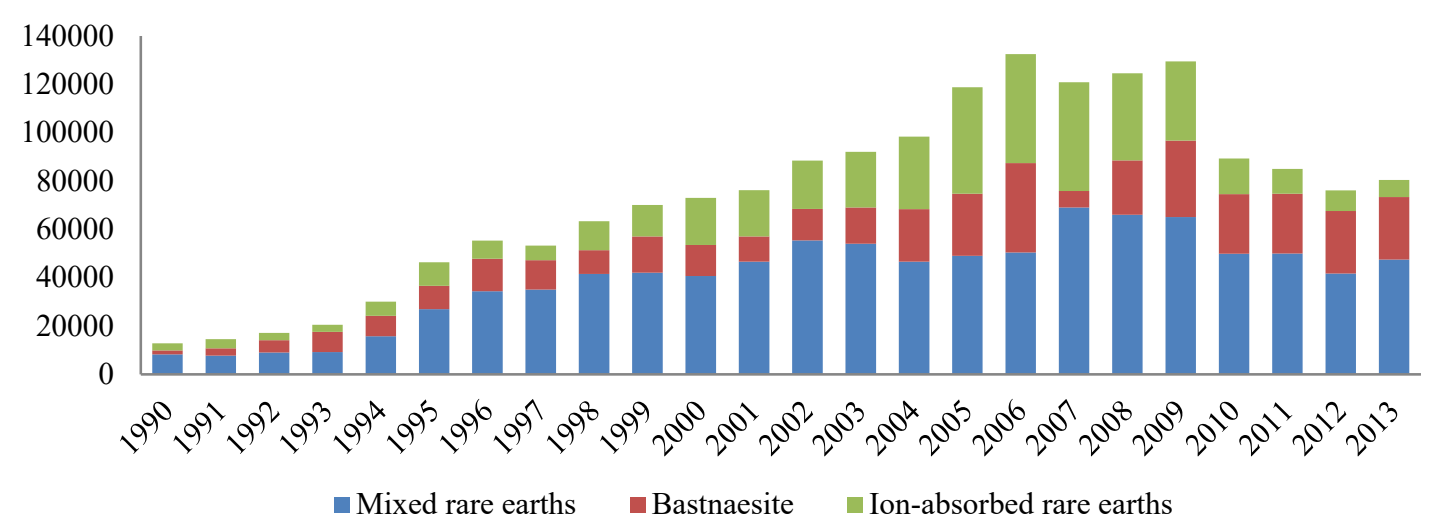

Figure 1. Production structure of major rare earth minerals in China from 1990 to 2013 (unit: REO, ton)

In the process of development and utilization of rare earth, pollutants that are harmful to the ecological environment will be produced during the stages of mining, smelting, and separation of rare earth resources. Different rare earth minerals will produce specific pollutants in different production links, resulting in different degrees of ecological damage. Rare earth minerals and their existing ecological environment problems are shown in Figure 2 below.

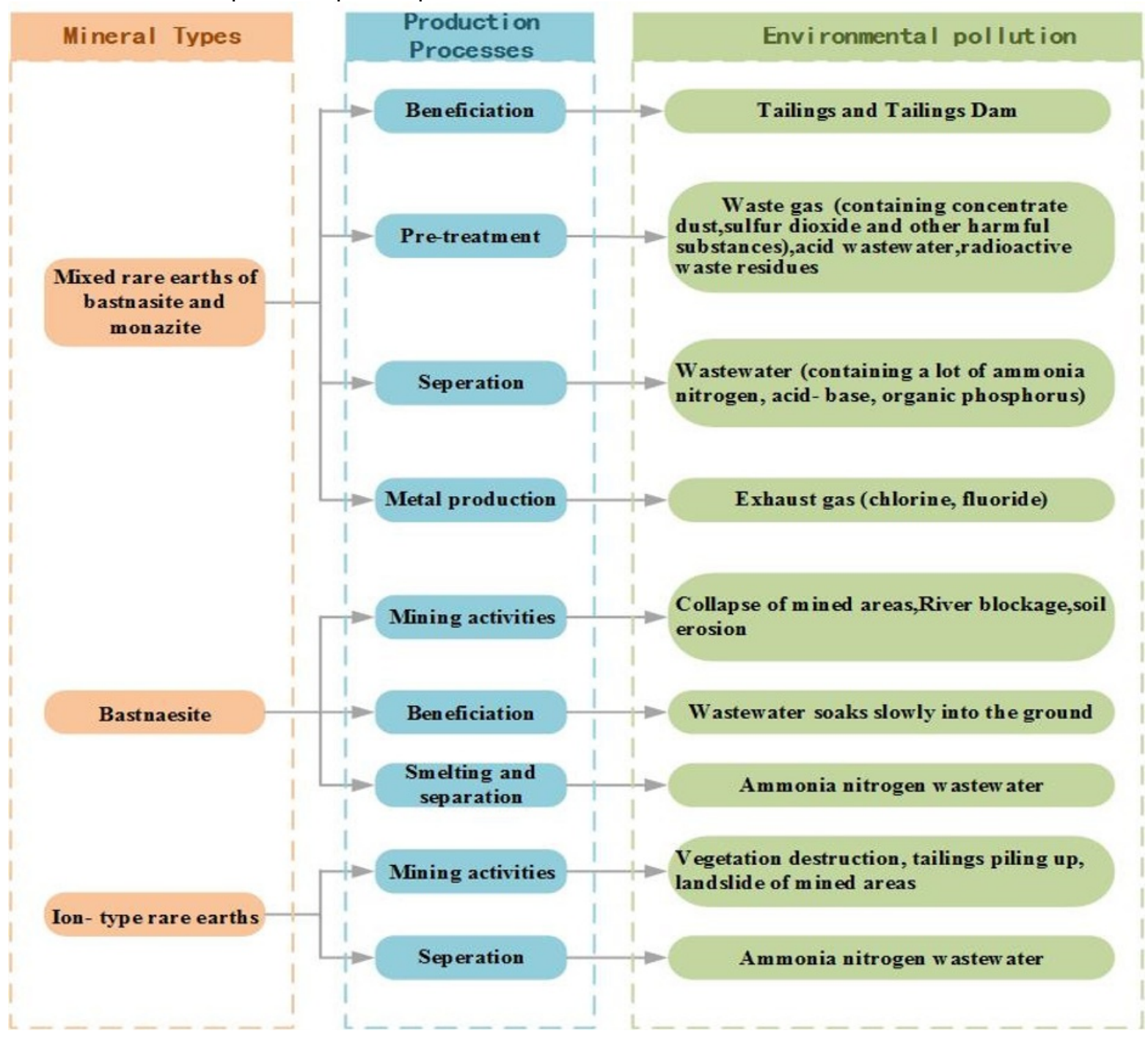

Figure 2. Rare Earth Mines and Environmental Problems

It is estimated that rare earth enterprises in China call for an average environmental cost of up to 5.6 US dollars/kg from 2002 to 2005, which shows that Chinese enterprises need to pay the huge environmental cost in the process of developing rare earth [24]. For a long time, due to the lack of effective control in the development of rare 
earth, the ecological environment has been seriously damaged. Therefore, relevant government departments have issued a series of laws and regulations from a macro perspective, focusing on the protective development of rare earth resources, improving the comprehensive utilization rate of rare earth resources and controlling the pollution caused by the development of rare earth to promote the sustainable and stable development of rare earth industry. Since 2000, the core legal policies promulgated have been shown in Table 1 below.

Table 1. Industrial policies of rare earth

\begin{tabular}{|c|c|}
\hline Time & Core Content \\
\hline 2000 & Implementing the mining quota system to control the amount of rare earth mining. \\
\hline 2002 & $\begin{array}{l}\text { Promulgating the "Interim Provisions on the Management of Foreign-invested Rare Earth } \\
\text { Industry" to further deepen the reform of using foreign capital in the rare earth industry. }\end{array}$ \\
\hline 2005 & Canceling the export tax rebate policy of rare earth. \\
\hline 2006 & Implementing the management system of total amount control indicators for rare earth mining. \\
\hline 2008 & $\begin{array}{l}\text { Promulgating the "Notice of the State Council on Comprehensively Rectifying and Regulating } \\
\text { the Order of Mineral Resources Exploitation" to implement the work by stages. }\end{array}$ \\
\hline 2009 & $\begin{array}{l}\text { Restricting the export of rare earth industry in China and carrying out the macro-control of the } \\
\text { rare earth industry through the " } 2009-2015 \text { Rare Earth Industry Development Plan". }\end{array}$ \\
\hline 2010 & $\begin{array}{l}\text { Promulgating the "Opinions on Promoting Mergers and Acquisitions of Enterprises" to promote } \\
\text { the scale development of rare earth enterprises. }\end{array}$ \\
\hline 2011 & $\begin{array}{l}\text { Promulgating the "Pollutant Emission Standards of Rare Earth Industry" to guide the } \\
\text { environmental management of rare earth industry. Putting forward "Several Opinions on } \\
\text { Promoting the Sustainable and Healthy Development of the Rare Earth Industry" to further } \\
\text { raise the awareness of the importance of effective protection and rational use of rare earth } \\
\text { resources. }\end{array}$ \\
\hline 2012 & $\begin{array}{l}\text { Promulgating the White Paper on "China's Rare Earth Conditions and Policies" to promote the } \\
\text { resource environment protection starting from the status quo and policies of rare earth industry } \\
\text { in China. }\end{array}$ \\
\hline 2013 & $\begin{array}{l}\text { Promulgating "Opinions on Promoting Mergers and Acquisitions of Key Enterprises," } \\
\text { indicating that the scale benefit of rare earth industry is significant, but there are still problems } \\
\text { such as unreasonable organizational structure. }\end{array}$ \\
\hline 2014 & $\begin{array}{l}\text { Including the "Regulations on the Management of Rare Metals" into the legislative plan. After } \\
\text { the introduction of this policy, effective legal control of rare earth metals such as rare earth in } \\
\text { China will be implemented }\end{array}$ \\
\hline 2016 & $\begin{array}{l}\text { Issuing the "Rare Earth Industry Development Plan (2016-2020)" to promote the sustainable } \\
\text { and stable development of rare earth industry scientifically. }\end{array}$ \\
\hline 2017 & $\begin{array}{l}\text { Issuing "Guidelines for the Development of Key Generic Technologies for Different Industries } \\
\text { (2017)", of which eight items are directly related to various fields of rare earth industry. }\end{array}$ \\
\hline
\end{tabular}

China accounts for about $23 \%$ of the world's rare earth reserves, but supplies more than $90 \%$ of the world's rare earth. China holds a monopoly position in rare earth export. The reason why China has obtained the monopoly position in export is mainly due to its price advantage without considering environmental costs[30]. Before 2006, due to the lack of effective control over the development of rare earths, rare earth development enterprises blindly exploited rare earths in pursuit of maximizing their own interests, and excessive development and inappropriate competition led to illegal phenomena such as illegal mining and smuggling in some enterprises. Such phenomena resulted in serious waste of rare earth resources. Rare earth production process has serious pollution hazards and high environmental costs. The production of 1 ton of rare earth oxides will produce 2,000 tons of tailings, 1,000 tons of wastewater containing heavy metals and 9600-12,000 cubic meters of sulphide and hydrofluoric acid [31]. In order to consolidate the status of rare earth as an important scarce strategic resource, conduct protective exploitation, the Ministry of Land and Resources has issued annual total mining control indicators (see Table 2), including ion-absorbed rare earths (mainly medium and heavy rare earths) and rockmineral rare earths (light rare earths) since 2006.

Table 2. Control Quantity of Rare Earth Mining in China from 2006 to 2018(Unit: REO, ton)

\begin{tabular}{cccc}
\hline Year & Light rare earths & $\begin{array}{c}\text { Medium and heavy rare } \\
\text { earths }\end{array}$ & Total \\
\hline 2006 & 78200 & 8320 & 86520 \\
2007 & 78200 & 8820 & 87020 \\
2008 & 78500 & 9120 & 87620 \\
2009 & 72300 & 10020 & 82320 \\
2010 & 77000 & 12200 & 89200
\end{tabular}




\begin{tabular}{lccc}
2011 & 80400 & 13400 & 93800 \\
2012 & 75900 & 17900 & 93800 \\
2013 & 75900 & 17900 & 93800 \\
2014 & 87100 & 17900 & 105000 \\
2015 & 87100 & 17900 & 105000 \\
2016 & 87100 & 17900 & 105000 \\
2017 & 87100 & 17900 & 105000 \\
2018 & 100850 & 19150 & 120000 \\
\hline
\end{tabular}

Data Source: Ministry of Land and Resources, the People's Republic of China

The strict implementation of normative actions such as "crime crackdown" in China's rare earth industry enables the rare earth resources to develop in a rational and orderly manner. At the same time, the main production areas have achieved remarkable results in harnessing the ecological damage caused by rare earth mining and the "three wastes" pollution caused by rare earth smelting. Sichuan Jiangtong Rare Earth Company has invested 683 million yuan to implement the mine environmental control and ecological restoration program, covering a total area of 107.7 hectares of reclamation and vegetation restoration. Baotou Iron and Steel Company has invested 2.2 billion yuan to implement the "three centralized" projects, namely, concentrated roasting, centralized smelting and separation and centralized wastewater treatment. In order to effectively control soil erosion, the mining sites of ionabsorbed rare earths in the South planted trees and grasses according to the requirements of "three no-retentionlandfill-greening" [32]. Some enterprises use waste for reprocessing to achieve "flexible mining" and sustainable social and economic development. "Elastic mining" is a process of tailings reprocessing. It is of great practical value to solve the high cost, high risk and stabilize of global supply chain caused by new mining [33]. When we use the term sustainability in mining, we do not mean "sustainable" mining, but mining that contributes appropriately to social sustainability [34]. At this level, under the control of policy, the output of rare earth exploitation is controlled or the ecological environment is harnessed effectively, which makes the social economy sustainable development. It can be understood that the development of rare earth has sustainability.

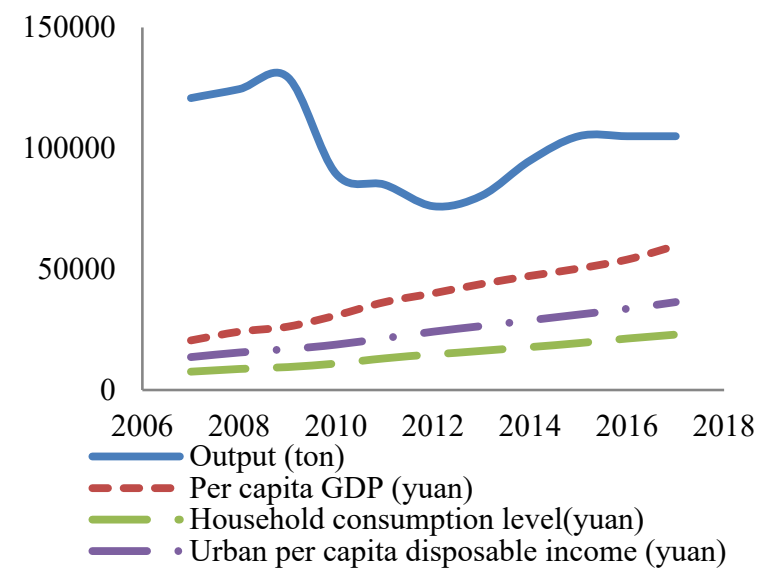

Figure 3. Trends of per capita GDP, rare earth production, consumption level and per capita disposable income of urban residents in China from 2007 to 2016
Data Sources: Ministry of Land and Resources of the People's Republic of China, National Statistical Bureau

From the macro control of rare earth development and production in China (see Figure 3), relevant government departments have introduced policies to control the annual production of rare earth resources to alleviate the environmental pollution caused by the development of rare earth resources. From 2010 to 2016, China's rare earth (REO) production is relatively stable. From 2012 to 2016, the output of rare earth (REO) in China was relatively stable. Compared with 2012 before, the production decreased significantly. Since 2007, China's per capita GDP, consumption level and per capita disposable income of urban residents have continued to grow. The whole economic environment has maintained good prospects. From this point of view, the substantial reduction of rare earth (REO) production has not exerted a negative impact on the economic and social life of residents. It can be preliminarily speculated that the decline of REO production may play a certain role in promoting social and economic development.

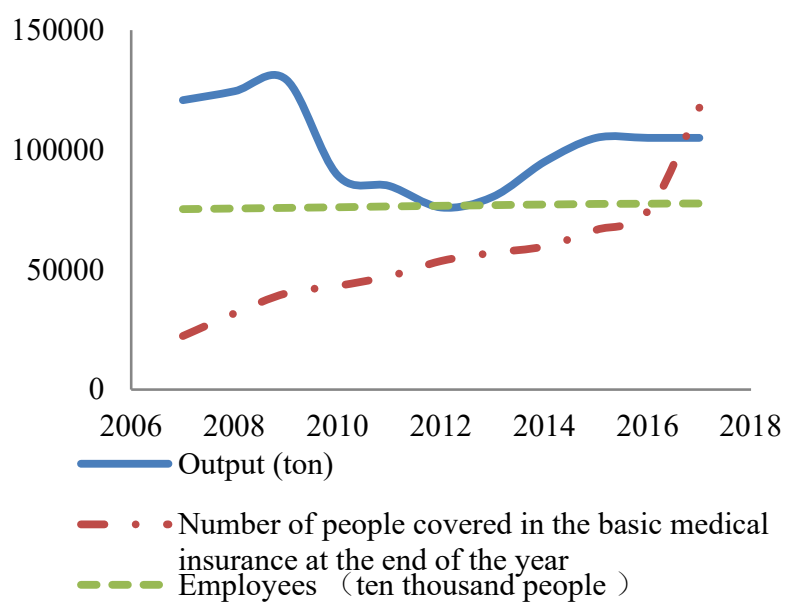

Figure 4. Trends in rare earth production, employment and medical insurance coverage in China from 2007 to 2016

Data Sources: Ministry of Land and Resources of the People's Republic of China, National Statistical Bureau

This paper illustrates the relationship between the output of rare earth resources development and social development from the macro level. As shown in Figure 4, in 2007-2012, influenced by industrial policies, the total output of rare earth industry showed a state of constant fluctuation. Employment remained stable during the same period, and the number of basic medical insurance insured at the end of the year increased. It can be approximately 
understood that the control of output has a positive effect on social development. It can be preliminarily concluded that the control of rare earth resources development will promote social development. The control of the development of rare earth resources is reflected in the regulation and enforcement of relevant laws and regulations on the development behavior of rare earth.

\section{Case Study}

\subsection{Research Design}

Alfred Marshall first proposed the theory of "external economy" in his book Principles of Economics [35]. Following Alfred Marshall, the theory of "external economy" was evolved into "externality" by A.C. Pigou and proposed the concept of "external uneconomic" [36]. Environmental externality is a special kind of external market effect. Environmental externalities are mainly negative in terms of production [37].Maibach et a, Brons and Christidis divided negative externalities into two categories: environmental impacts and socio-economic impacts1[38-39]. Therefore, the environmental pollution caused by the development of rare earth can be understood as a negative environmental externality caused by the development of rare earth.

The rare earths in Jiangxi Province occupy a large proportion in China. Ion-adsorbed rare earth deposits were first discovered in Jiangxi Province in the late 1960s. Since then, they have been found in Fujian, Hunan, Guangdong, Guangxi and other Nanling areas, but Jiangxi Province is relatively concentrated and abundant[40].Therefore, taking Jiangxi Province as the research object of the case has strong practical value. Due to the excessive development of rare earth resources, a series of negative environmental externalities such as vegetation damage and excessive discharge of three wastes will occur. To treat negative environmental externalities, relevant government departments will formulate policies and regulations to rectify the rare earth industry to achieve the restoration of the ecological environment. The effective implementation of policies will have a controlling effect on the development of rare earth resources, and meanwhile, environmental problems caused by the improper development of rare earth resources will be alleviated. The effectiveness of the treatment of environmental issues is closely related to the effectiveness of policy implementation, while the effectiveness of policy implementation can be measured by policy efficiency. After that, the relationship between policy efficiency and social and economic development is studied based on the measurement of policy efficiency. The higher the policy efficiency, the less the negative environmental externalities caused by rare earth development. Thus, the social and economic development will be affected positively. The overall research design of this paper is shown in Figure 5.

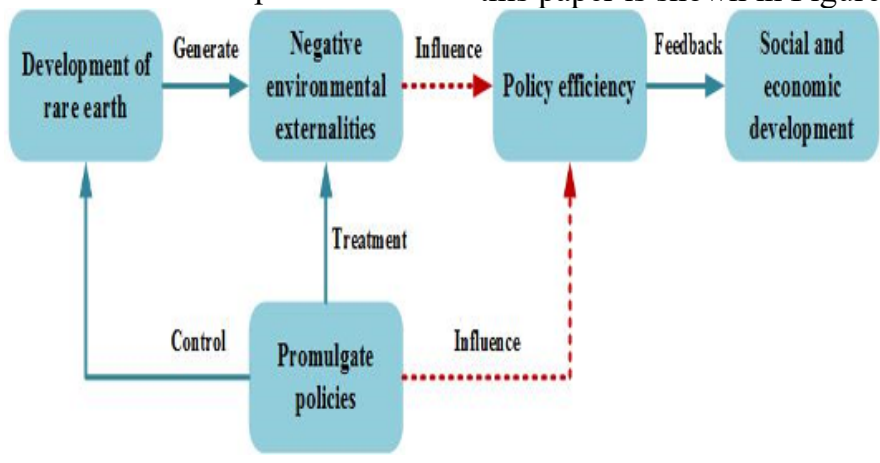

Figure 5. Research design flow chart

\subsection{Method Selection}

To avoid the drawbacks in the traditional DEA models, such as not considering the factors like slacks and random errors[41], this paper uses the non-radial SBM method to achieve the precious measurement of policy efficiency. Policy efficiency output is studied from three dimensions: vegetation damage, water pollution, and air pollution. Each dimension includes multiple specific measurement indicators. The entropy weight method is used in this paper to determine the weight of each indicator to avoid the influence of subjective factors. On this basis, the water pollution indicator and the air pollution indicator are calculated. The policy efficiency value is calculated after the forward processing of the contrary indicator. The larger the value obtained, the more effective the policy implementation. The entropy method is also used in the measurement of social and economic development, which forms the economic development indicator, the social development indicator, and the socio-economic development indicator. Finally, this paper intends to use gray correlation analysis method to study the impact and effect of policy efficiency on social and economic development, to analyze the feedback relevance between policy implementation and economic development, social development, and the overall socio-economic development.

\subsection{Indicator Selection and Data Source}

Based on the perspective of input and output, this paper establishes the policy efficiency evaluation indicator system (see Table 4 below for details). The policy input indicator includes the number of central regulations and local regulations related to the rare earth industry, and the number of regulations comes from the pkulaw legal database. Five-time periods are divided, namely 1998- 
2001, 2002-2005, 2006-2009, 2010-2013, and 2014-2017. The total number of regulations in each region is shown in Table 3 below. The output includes three factors: vegetation damage, water pollution, and air pollution caused by the development of rare earth resources. The corresponding total damaged vegetation area, water pollution indicator, and air pollution indicator can be

Table 3. Total investment in Jiangxi, Inner Mongolia, Guangdong, Sichuan and Fujian from 1998 to 2017

\begin{tabular}{|c|c|c|c|c|c|}
\hline \multirow{2}{*}{ Region } & \multicolumn{5}{|c|}{ Period } \\
\hline & $1998-2001$ & $2002-2005$ & 2006-2009 & 2010-2013 & 2014-2017 \\
\hline Jiangxi & 4 & 5 & 39 & 74 & 38 \\
\hline Inner Mongolia & 8 & 5 & 26 & 65 & 53 \\
\hline Guangdong & 6 & 6 & 25 & 66 & 31 \\
\hline Sichuan & 6 & 5 & 26 & 56 & 28 \\
\hline Fujian & 6 & 5 & 23 & 60 & 27 \\
\hline
\end{tabular}

Table 4. Evaluation indicator system of policy efficiency

\begin{tabular}{|c|c|c|c|}
\hline $\begin{array}{l}\text { Target } \\
\text { layer }\end{array}$ & Criterion layer & Indicator layer & Indicator interpretation \\
\hline \multirow{8}{*}{$\begin{array}{l}\text { Policy } \\
\text { efficiency }\end{array}$} & Input indicator & $\begin{array}{l}\text { Number of } \\
\text { central } \\
\text { regulations } \\
\text { Number of local } \\
\text { regulations }\end{array}$ & Number of central regulations in a specified period \\
\hline & \multirow{7}{*}{ Output indicator } & $\begin{array}{l}\text { Vegetation } \\
\text { deterioration }\end{array}$ & Total damaged vegetation area $\left(\mathrm{km}^{2}\right)$ \\
\hline & & \multirow{4}{*}{ Water pollution } & $\begin{array}{c}\text { Amount of waste water in the smelting industry }(10,000 \\
t) \\
\text { Amount of waste water in the smelting of COD }(t) \\
\text { Amount of waste water in the smelting of ammonia } \\
\text { nitrogen }(t)\end{array}$ \\
\hline & & & $\begin{array}{l}\text { Amount of waste water in the smelting of heavy metal } \\
\qquad \text { lead }(\mathrm{kg})\end{array}$ \\
\hline & & & $\begin{array}{l}\text { Amount of waste water in the smelting of fluoride } \\
\text { (liquid) }(\mathrm{t})\end{array}$ \\
\hline & & & $\begin{array}{l}\text { Amount of waste water in the smelting of phosphorus } \\
\qquad(\mathrm{kg})\end{array}$ \\
\hline & & \multirow{2}{*}{ Air pollution } & $\begin{array}{l}\text { Amount of industrial waste gas } \\
\text { Amount of waste gas in the smelting of smoke and dust } \\
\text { (t) }\end{array}$ \\
\hline & & & $\begin{array}{l}\text { Amount of waste gas in the smelting of } \mathrm{SO}_{2}(\mathrm{t}) \\
\text { Amount of waste gas in the smelting of solid waste } \\
\text { (waste residue) }(\mathrm{t})\end{array}$ \\
\hline
\end{tabular}

The selection of the evaluation indicator of economic and social development level starts with economic development and social development. Economic development indicators include per capita GDP, household consumption level and average income of on-post staff in cities and towns (yuan); social development indicators involve the number of staff covered in basic medical insurance (10,000 people), registered unemployment rate in cities and towns and urbanization rate (see Table 5 for details). The basic data comes from the National Bureau of Statistics.

understood as negative environmental externalities. The specific explanation of these three indicators is detailed in the indicator interpretation in Table 4 below. The basic data are derived from the public information of rare earth industry and some missing values are obtained by using the mean method to calculate the growth rate. 
measure the economic development indicator and the social development indicator.

Table 5. Evaluation indicator system of economic and social development level

\begin{tabular}{ccc}
\hline $\begin{array}{c}\text { Target } \\
\text { layer }\end{array}$ & Criterion layer & $\begin{array}{c}\text { Indicator } \\
\text { layer }\end{array}$ \\
\hline $\begin{array}{c}\text { Economic and social development } \\
\text { level }\end{array}$ & Economic development & $\begin{array}{c}\text { Per capita GDP } \\
\text { Household consumption level } \\
\text { The average income of on-post staff in cities and } \\
\text { towns (yuan) } \\
\text { Number of staff covered in basic medical } \\
\text { insurance (10,000 people) }\end{array}$ \\
& Social development & $\begin{array}{c}\text { The registered unemployment rate in cities and } \\
\text { towns }\end{array}$ \\
& & Urbanization rate \\
\hline
\end{tabular}

Table 6. Entropy weight of negative environmental externality indicators and socio-economic development indicators (single)

\begin{tabular}{|c|c|c|c|c|c|}
\hline Indicator & 2001 & 2005 & 2009 & 2013 & 2017 \\
\hline $\begin{array}{l}\text { Amount of waste water in the smelting industry } \\
\qquad(10,000 \mathrm{t})\end{array}$ & 0.1625 & 0.1817 & 0.1911 & 0.2195 & 0.2249 \\
\hline $\begin{array}{l}\text { Amount of waste water in the smelting of COD } \\
(\mathrm{t})\end{array}$ & 0.1663 & 0.1407 & 0.1480 & 0.1492 & 0.1403 \\
\hline $\begin{array}{c}\text { Amount of waste water in the smelting of } \\
\text { ammonia nitrogen }(\mathrm{t})\end{array}$ & 0.1466 & 0.1790 & 0.1271 & 0.1051 & 0.1754 \\
\hline $\begin{array}{l}\text { Amount of waste water in the smelting of heavy } \\
\text { metal lead }(\mathrm{kg})\end{array}$ & 0.1664 & 0.1409 & 0.1535 & 0.1496 & 0.1422 \\
\hline $\begin{array}{c}\text { Amount of waste water in the smelting of } \\
\text { fluoride (liquid) }(\mathrm{t})\end{array}$ & 0.1777 & 0.1852 & 0.1918 & 0.1573 & 0.1495 \\
\hline $\begin{array}{c}\text { Amount of waste water in the smelting of } \\
\text { phosphorus }(\mathrm{kg})\end{array}$ & 0.1805 & 0.1532 & 0.1674 & 0.1725 & 0.1631 \\
\hline Amount of industrial waste gas & 0.2371 & 0.2075 & 0.2228 & 0.1074 & 0.0916 \\
\hline $\begin{array}{c}\text { Amount of waste gas in the smelting of smoke } \\
\text { and dust (t) }\end{array}$ & 0.2175 & 0.1908 & 0.1989 & 0.1165 & 0.0964 \\
\hline Amount of waste gas in the smelting of $\mathrm{SO}_{2}(\mathrm{t})$ & 0.2836 & 0.2516 & 0.2706 & 0.1254 & 0.1146 \\
\hline $\begin{array}{c}\text { Amount of waste gas in the smelting of solid } \\
\text { waste (waste residue) (t) }\end{array}$ & 0.2618 & 0.2264 & 0.2451 & 0.1313 & 0.1197 \\
\hline Per capita GDP & 0.1293 & 0.3284 & 0.4097 & 0.4623 & 0.5963 \\
\hline Household consumption level & 0.1081 & 0.2770 & 0.3313 & 0.2782 & 0.3841 \\
\hline $\begin{array}{c}\text { Average income of on-post staff in cities and } \\
\text { towns (yuan) }\end{array}$ & 0.1138 & 0.1295 & 0.1752 & 0.3622 & 0.2097 \\
\hline $\begin{array}{l}\text { Number of staff covered in basic medical } \\
\text { insurance }(10,000 \text { people })\end{array}$ & 0.2059 & 0.0327 & 0.0254 & 0.0501 & 0.0558 \\
\hline $\begin{array}{c}\text { Registered unemployment rate in cities and } \\
\text { towns }\end{array}$ & 0.0607 & 0.4485 & 0.4923 & 0.4939 & 0.5629 \\
\hline Urbanization rate & 0.3822 & 0.0021 & 0.3868 & 0.6322 & 0.4380 \\
\hline
\end{tabular}

Table 7. Entropy weigh of economic development indicators and social development indicators (overall)

\begin{tabular}{ccccccc}
\hline & Indicator & 2001 & 2005 & 2009 & 2013 & 2017 \\
\hline \multirow{2}{*}{$\begin{array}{c}\text { Economic } \\
\text { development }\end{array}$} & $\begin{array}{c}\text { Per capita GDP } \\
\text { Household consumption level } \\
\text { Average income of on-post staff in } \\
\text { cities and towns (yuan) }\end{array}$ & 0.3681 & 0.3376 & 0.3944 & 0.3875 & 0.3744 \\
$\begin{array}{c}\text { Social } \\
\text { development }\end{array}$ & $\begin{array}{c}\text { Number of staff covered in basic } \\
\text { medical insurance (10,000 people) }\end{array}$ & 0.3241 & 0.3254 & 0.2454 & 0.2064 & 0.2670 \\
& $\begin{array}{c}\text { Registered unemployment rate in cities } \\
\text { and towns }\end{array}$ & 0.0935 & 0.2546 & 0.1660 & 0.1833 & 0.1699 \\
\hline Urbanization rate & 0.5891 & 0.3733 & 0.2461 & 0.2088 & 0.2488 \\
\hline
\end{tabular}




\subsection{Research Results and Analysis}

\subsubsection{Analysis of pollution indicator and socio- economic development indicator}

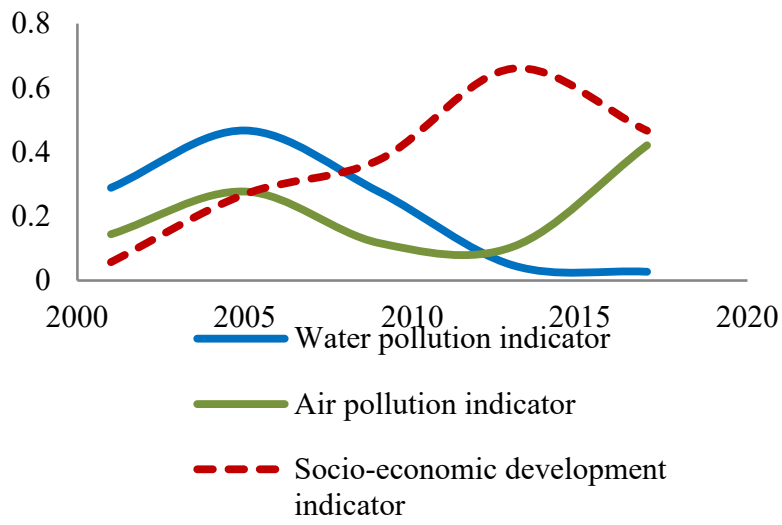

Figure 6. Tendency chart of water pollution indicator, air pollution indicator and socio-economic development indicator of Jiangxi Province in five years

It can be seen from Fighue 6 that the variation trend of water pollution indicator, air pollution indicator, and socio-economic development indicator in Jiangxi Province tend to be consistent before 2005, namely a continuously rising trend. The greater the water pollution indicator and the air pollution indicator, the more severe the pollution of the ecological environment; the larger the socio-economic development indicator, the higher the socio-economic development level, indicating that the socio-economic development in Jiangxi Province is largely relying on the consumption of resources at this moment. The cost of socio-economic development is increased at the expense of the environment, which has exerted a negative impact on the environment. Since then, both the water pollution indicator and the air pollution indicator have declined, and meanwhile, the overall socioeconomic development has increased in an continuous way, reflecting that the phenomenon of over-reliance on resources in Jiangxi Province has been alleviated and the utilization rate of rare earth resources has been improved. The socio-economic development pays more attention to the sustainability of resources and the environment, which verifies the feedback effect of the overall policy implementation effect on socio-economic development.

\subsubsection{Evaluation of policy efficiency}

Table 8. Policy efficiency value of Jiangxi, Inner Mongolia, Guangdong, Sichuan, and Fujian in five years

\begin{tabular}{|c|c|c|c|c|c|c|c|}
\hline \multirow{2}{*}{ Efficiency } & \multirow{2}{*}{ Region } & \multicolumn{5}{|c|}{ Year } & \multirow{2}{*}{$\begin{array}{l}\text { Mean } \\
\text { value }\end{array}$} \\
\hline & & 2001 & 2005 & 2009 & 2013 & 2017 & \\
\hline \multirow{5}{*}{$\begin{array}{c}\text { Policy efficiency of } \\
\text { vegetation } \\
\text { deterioration }\end{array}$} & Jiangxi & 1.0000 & 0.8000 & 0.1026 & 0.0541 & 0.1053 & 0.4124 \\
\hline & $\begin{array}{c}\text { Inner } \\
\text { Mongolia }\end{array}$ & 0.2119 & 0.2754 & 0.0657 & 0.0267 & 0.0346 & 0.1229 \\
\hline & Guangdong & 0.2502 & 0.3353 & 0.0621 & 0.0157 & 0.0305 & 0.1388 \\
\hline & Sichuan & 0.1125 & 0.1197 & 0.0286 & 0.0104 & 0.0206 & 0.0584 \\
\hline & Fujian & 0.0606 & 0.0727 & 0.0158 & 0.0061 & 0.0135 & 0.0337 \\
\hline \multirow{5}{*}{$\begin{array}{l}\text { Policy efficiency of } \\
\text { water pollution }\end{array}$} & Jiangxi & 0.6047 & 0.5811 & 0.0440 & 0.0124 & 0.0209 & 0.2526 \\
\hline & $\begin{array}{c}\text { Inner } \\
\text { Mongolia }\end{array}$ & 0.8435 & 1.0000 & 0.2307 & 0.1009 & 0.1286 & 0.4607 \\
\hline & Guangdong & 0.1251 & 0.0347 & 0.0077 & 0.0096 & 0.0201 & 0.0394 \\
\hline & Sichuan & 0.2479 & 0.2818 & 0.0550 & 0.0390 & 0.0850 & 0.1418 \\
\hline & Fujian & 0.1037 & 0.0006 & 0.0002 & 0.0104 & 0.0234 & 0.0277 \\
\hline \multirow{5}{*}{$\begin{array}{l}\text { Policy efficiency of } \\
\text { air pollution }\end{array}$} & Jiangxi & 0.0919 & 0.1137 & 0.0084 & 0.0042 & 0.0207 & 0.0478 \\
\hline & $\begin{array}{c}\text { Inner } \\
\text { Mongolia }\end{array}$ & 0.2072 & 0.2943 & 0.0444 & 0.0023 & 1.0000 & 0.3097 \\
\hline & Guangdong & 0.0277 & 0.0300 & 0.0068 & 0.0122 & 0.0055 & 0.0164 \\
\hline & Sichuan & 0.0397 & 0.0664 & 0.0113 & 0.0033 & 0.2703 & 0.0782 \\
\hline & Fujian & 0.0251 & 0.0301 & 0.0066 & 0.0146 & 0.0056 & 0.0164 \\
\hline
\end{tabular}

The policy efficiency value of Jiangxi, Inner Mongolia, Guangdong, Sichuan, and Fujian provinces have experienced different degrees of loss during the research year. The policy efficiency of vegetation deterioration, water pollution, and air pollution has shown a continuous fluctuating trend during the research year. It is worth noting that, in recent years, the policy implementation efficiency of vegetation deterioration in Jiangxi Province is obvious from the annual data. However, the policy implementation efficiency is lower than that of Inner
Mongolia in terms of the efficiency of water pollution policy. Also, the policy implementation efficiency of air pollution is at a lower level among these five provinces. This characteristic can also be observed from the mean value of policy efficiency in Table 8. Jiangxi Province should further promote the control and protection of air pollution, actively implement environmental regulations related to the development of rare earth, and improve traditional development and smelting process to minimize air pollution emissions. 


\subsubsection{Analysis of grey correlation between policy efficiency and socio-economic development}

Table 9. Grey correlation of Jiangxi, Inner Mongolia, Guangdong, Sichuan and Fujian in five years

\begin{tabular}{|c|c|c|c|c|}
\hline \multirow[b]{2}{*}{$\begin{array}{l}\text { Explained variable } \\
\text { (Y) }\end{array}$} & \multirow[b]{2}{*}{ Region } & \multicolumn{3}{|c|}{ Explanatory variable $(\mathrm{X})$} \\
\hline & & $\begin{array}{c}\text { Policy efficiency of } \\
\text { vegetation } \\
\text { deterioration }\left(\mathrm{X}_{1}\right) \\
\end{array}$ & $\begin{array}{l}\text { Policy efficiency of } \\
\text { water pollution }\left(\mathrm{X}_{2}\right)\end{array}$ & $\begin{array}{c}\text { Policy efficiency of air } \\
\text { pollution }\left(\mathrm{X}_{3}\right)\end{array}$ \\
\hline \multirow{5}{*}{$\begin{array}{l}\text { Socio-economic } \\
\text { development } \\
\text { indicator }\left(\mathrm{Y}_{1}\right)\end{array}$} & Jiangxi & 0.6540 & 0.7802 & 0.7344 \\
\hline & Inner Mongolia & 0.6100 & 0.6046 & 0.6983 \\
\hline & Guangdong & 0.6123 & 0.6708 & 0.7093 \\
\hline & Sichuan & 0.6611 & 0.7230 & 0.6962 \\
\hline & Fujian & 0.7899 & 0.7976 & 0.8597 \\
\hline \multirow{5}{*}{$\begin{array}{c}\text { economic } \\
\text { development } \\
\text { indicator }\left(\mathrm{Y}_{2}\right)\end{array}$} & Jiangxi & 0.6932 & 0.7363 & 0.7089 \\
\hline & Inner Mongolia & 0.6144 & 0.6091 & 0.7346 \\
\hline & Guangdong & 0.5909 & 0.6553 & 0.6919 \\
\hline & Sichuan & 0.6166 & 0.6440 & 0.6828 \\
\hline & Fujian & 0.6304 & 0.6128 & 0.7165 \\
\hline \multirow{5}{*}{$\begin{array}{l}\text { Social development } \\
\text { indicator }\left(\mathrm{Y}_{3}\right)\end{array}$} & Jiangxi & 0.7571 & 0.7066 & 0.7632 \\
\hline & Inner Mongolia & 0.7411 & 0.7246 & 0.6194 \\
\hline & Guangdong & 0.5841 & 0.6171 & 0.6956 \\
\hline & Sichuan & 0.7760 & 0.8132 & 0.6770 \\
\hline & Fujian & 0.6752 & 0.6556 & 0.7775 \\
\hline
\end{tabular}

The measurement result of the grey correlation is shown in Table 9. Here, socio-economic development $\left(\mathrm{Y}_{1}\right)$, economic development $\left(\mathrm{Y}_{2}\right)$, and social development $\left(\mathrm{Y}_{3}\right)$ are designated as explained variables, while policy efficiency of vegetation deterioration $\left(\mathrm{X}_{1}\right)$, policy efficiency of water pollution $\left(\mathrm{X}_{2}\right)$ and policy efficiency of air pollution $\left(\mathrm{X}_{3}\right)$ are designated as an explanatory variable. The values of the two variables are composed of the values in each region in five years, and the correlation is measured at the level of the resolution coefficient $\rho=0.5$. In general, the feedback correlation in Jiangxi Province is higher, and the feedback correlation between policy efficiency and social development indicator is the greatest. From the perspective of economic development level, the feedback correlation between the policy efficiency of air pollution and the implementation efficiency of water pollution and to the socio-economic development indicator is significant, and this correlation is the most significant in Jiangxi Province. From the perspective of social development level, the correlation between the policy efficiency of air pollution and social development indicator is the most significant. Among all the research areas, the correlation in Fujian Province is the highest, which is 0.7775 , while that in Inner Mongolia is the lowest. From the overall level of socio-economic development, the feedback correlation between the policy efficiency of air pollution and socio-economic development indicator is the most significant under the promoting effect of social development indicator. This correlation is the highest in Fujian Province, reaching 0.8597 while this correlation is the lowest in Guangdong Province.

\section{Conclusions and Recommendations}

In this paper, we have emphasized the relationship between the effective implementation of rare earth industry policy and social and economic development through macro analysis and case study. China has abundant rare earth resources, which is a unique advantage for the industrial development in China. However, the rapid social and economic development in China cannot be achieved at the expense of the ecological environment. Through the above analysis in this paper, the following conclusions can be obtained, and some suggestions can be proposed for reference:

(1) China has reduced its reliance on rare earth resources in recent years, but it still needs to improve its industrial structure and reduce environmental and ecological costs. Rare earth is an important strategic reserve resource, and emphasis should be given on protective development, improving the utilization rate and recovery rate of rare earth resources. People should pay attention to the recovery of rare earth from rare earth waste such as waste rare earth polishing powder and waste nickel-metal hydride battery. At the same time, it is necessary to introduce research talents in the field of rare earth, achieve independent innovation in processing and technology and break down technical barriers. Researchers should study green extraction technology of rare earth mine so that the mining and smelting technology can develop towards the direction of clean, non-toxic and efficient and the optimization and upgrading of rare earth industry can be promoted. Manufacturing enterprises can cooperate with universities and research institutions to accelerate the renewal of production concepts and processes. Also, enterprises can be merged and reorganized, so that the resources can be concentrated and uniformly configured. Some enterprises can extend and integrate the industrial chain by intervening in the upstream and downstream of rare earth industry, to form industrial clusters, achieve scale effect and minimize the waste of resources.

(2) Although the policy system of rare earth industry in China has been gradually improved, the efficiency of implementation needs to be improved and the mechanism 
of supervision and guarantee should be strengthened. From the results of case studies, The implementation effect of vegetation deterioration policy in Jiangxi Province is relatively obvious while that of air pollution policy is relatively weak. Because Jiangxi Province has certain representativeness, rare earth development and processing enterprises of China need to strictly control the emission of harmful substances by the standards listed in the "Discharge Standard of Pollutants of Rare Earth Industry" and change the existing competition strategy in production and operation, from low cost to product differentiation at the source. In terms of policy formulation, eco-sustainability should be regarded as the top priority, and the environmental protection legal system should be improved in every link from the development of rare earth to the processing of rare earth products. The blanks in pollution prevention and control should be filled in from details. From fiscal taxation policy, the corporate income tax should be reduced or preferential policies such as tax rebate should be implemented for enterprises which use waste rare earth mines for recycling and reproduction and produce products with low ecological costs. Also, it is necessary to adjust the tax difference between rare earth resources and other varieties of mineral. In terms of policy implementation, the excessive consumption of low-end products or products with high ecological costs should be controlled and effective monitoring should be implemented in various production links to urge enterprises to achieve clean production. Enterprises with heavy pollution in rare earth industry should be severely punished, and one-vote veto should be implemented to resolutely eliminate enterprises with backward production capacity. Emphasis should be given on the application of cleaning patents in rare earth processing and special awards should be given to outstanding contributors.

(3) Effective implementation of rare earth industry policy has a feedback effect on social and economic development. If the ecological environment is seriously damaged, the external environment will react upon social and economic development and both the economic environment and social life will be adversely affected. And the degree of impact is related to the effectiveness of policy implementation. The case study indicates that the feedback effect of policy implementation on social development is most obvious, in which the policy efficiency of air pollution and water pollution policy are the most prominent. The feedback of policy implementation efficiency on economic and social development will further improve the policy efficiency, especially strengthening the implementation of air pollution policy and water pollution policy. In view of this, China should achieve coordinated economic, social and ecological development on the basis of ensuring the sustainability of resources and environment. On the one hand, it is necessary to raise awareness of enterprises and the public on the important relationship between the development of rare earth resources and environmental protection, so that the promulgation of policies can be positively responded and quickly implemented; on the one hand, relevant government departments need to track the implementation of policies in a timely manner, identify difficulties in policy implementation and improve the internal and external information feedback mechanism.

\section{Acknowledgments}

This article was funded by General project of humanities and social science research of the Ministry of Education (15YJC790076) and Open Fund project of soft science research and cultivation base in Jiangxi Province (17RJJ02).

\section{References}

1. Kooroshy, J., Tiess, G., Tukker, A., Walton, A.Strengthening the European Rare Earths Supply Chain: Challenges and Policy Options. The European Rare Earths Competency Network (ERECON) Report, 2015

2. United States Geological Survey (USGS), 2017. Minerals commodity Summaries, Rare Earths, January 2017

3. Yang,Z.F., Ma,Y., Wang,Y., Mining.Beneficiation and Environmental Protection of Rare Earth . Beijing: Metallurgical Industry Press, 2018

4. Department of ecological resources in Jiangxi Province: Comprehensively promote the ecological restoration of rare earth mines In Ganzhou .http://www.jxepb.gov.cn/hbxc/hbtp/2018/d 0be25235beb4a5c99c2d640673387f8.htm (2018.01.24)

5. Gueroult.R., Rax,J.M., Fisch,N.J. Opportunities for plasma separation techniques in rare earth elements recycling.Journal of Cleaner Production, 2018, 182: 1060 1069

6. Lan,X., Gao,J.T., Du,Y., Guo.Z.C.Mineral evolution and separation of rare-earth phases from Bayan Oborare-earth concentrate in a super-gravity field. Journal of Alloys and Compounds, 2018, 731: $873 \sim 880$

7. Bouchmila,I., Kefi,B.B., Souissi,R., Abdellaoui,M. Purification, characterization and application of cherty rocks as sorbent for separation and preconcentration of rare earths.Journal of Materials Research and Technology,2019,8:2910 2923

8. Zhang,B., Liu,C.J., Li,C.L., Jiang,M.F..A novel approach for recovery of rare earths and niobium from Bayan Obo tailings. Minerals Engineering, 2014,65:17 23

9. Bandara, H.M.D., Field, K.D., Emmert, M.H. Rare earth recovery from end-of life motors employing green chemistry design principles. Green Chem, 2016, 18:753 759

10. Mondala,S., Gharb,A., Satpatic,A.K., Sinharoyd,P., Singha,D.K., Sharmad,J.N., Sreenivasa.T., Kain,V.Recovery of rare earth elements from coal fly ash using TEHDGA impregnated resin. Hydrometallurgy,2019,185:93 101

11. Hisada,M., Kawase,Y. Recovery of rare-earth metal neodymium from aqueous solutions bypoly-g- 
glutamic acid and its sodium salt as biosorbents: Effects ofsolution $\mathrm{pH}$ on neodymium recovery mechanisms. Journal of Rare Earths, 2018, 36: $528 \sim 536$

12. Ulmer, U., Asano, K., Patyk, A., Enoki, H., Nakamura, Y., Pohl, A., Dittmeyer, R., Fichtner, M.. Cost reduction possibilities of vanadium-based solid solutions -microstructural, thermodynamic, cyclic and environmental effects of ferrovanadium substitution.J.AlloysCompd,2015,648(11):1024 103 0

13. American Chemistry Council [ACC]. The economic benefits of the North American rare earth industry. Rare Earth Technology Alliance for the ACC,2014

14. McLellan,B.C., Corder,G.D., Golev,A., Ali,S.H.Sustainability of the Rare Earths Industry. Environmental Sciences,2014,20:280 287

15. Klinger,J.M. Rare earth elements: Development, sustainability and policy issues. The Extractive Industries and Society,2018,5:1 7

16. HONG,F. Rare Earth: Production, Trade and Demand. Journal of Iron and Steel Research, International. 2006,13:33 38

17. Mancheri,N.A.World trade in rare earths, Chinese export restrictions, and implications. Resources Policy,2015,46:262 271

18. Hou,W.Y., Liu,H.F., Wang,H., Wu,FY Structure and patterns of the international rare earths trade: A complex network analysis.Resources Policy, 2018, 55:133 142

19. Wübbeke, J. Rare earth elements in China: policies and narratives of re inventing an industry. Resour. Policy,2013,38:384 394

20. Zhang,L., Guo,Q., Zhang,J.B., Huang.Y., Xiong,T.Did China's rare earth export policies work? - Empirical evidence from USA and Japan. Resources Policy,2015,43:82 90

21. Packey,D.J., Kingsnorth, D.The impact of unregulated ionic clay rare earth mining in China. Resources Policy,2016,48:112 116

22. Ni,P.P.,Meng,Y.B.,Yang, B.Exploitation and Utilization Status and Protective Development Strategies of Rare Earth Resources in China . Macroeconomics,2010,10:13 20

23. Fang,Y.P., Tao,Y.L., Li,X.Y., Ma,P., Guo,J.Opportunities and Challenges of China's Rare Earth Industry: from the Perspective of Policy Implementation Effect . China Mining Magazine, 2014,23:4 8

24. Liu,G.C., Tan J.Y. Problem and Policy Orientation of Low-Carbon Development of Rare Earth Industry in China . Economic Review,2014,04:39 42

25. Yang L.M., Cai.L.H.,Influence Factors of Sustainable Development of Rare Earth Industry and Caping Strategy. Chinese Rare Earths,2015,36:149 154

26. Wang,Y.Z.Empirical Research on the Policy Effect of Rare Earth Industry in China. Macroeconomics, 2015, 02:39 49
27. He,H.L., Feng,M.Z.An Empirical Study of the Evaluation for China's Rare Earth Exporting . World Economy Studies,2017,11:88 99

28. Amsden, A.H., Asia's Next Giant: South Korea's Late Industrialization. New York : Oxford University Press, 1989

29. Sun,Z., Xi,J.C.Threshold Effect of Marketization and Differentiated Industrial Policy. Research on Economics and Management,2016,37:21 31

30. MORRISON W M and TANG R. China's Rare Earth Industry and Export Regime: Economic and Trade Implications for the United State. Congressional Research Service, 2012

31. PACKEY D J, KINGSNORTH D. The impact of unregulated ionic clay rare earth mining in China. Resources Policy,2016,48:112 116

32. Liu, Y., Environmental Protection and Effectiveness of Rare Earth Industry in Recent Years in China. Rare Earth Information,2014,06:36 39

33. Knapp, Freyja L.The birth of the flexible mine: changing geographies of mining and the E-waste commodity frontier. Environ. Plann A,2016,48:1 21

34. McLellan, BC. Corder, GD. Ali, SH. Sustainability of Rare Earths-An Overview of the State of Knowledge. Minerals,2013,03,304 317

35. Marshall. Principles of Economics. Beijing: the Commercial Press, 1964

36. A.C. Pigou. Welfare Economics. Beijing: the Commercial Press, 2006

37. Eidelwein, F., et al. Internalization of environmental externalities: development of a method for elaborating the statement of economic and environmental results. J. Clean. Prod., 2017. 1e15

38. Maibach, M., Schreyer, C., Sutter, D., Van Essen, H.P., Boon, B.H., Smokers, R., Schroten, A., Doll, C., Pawlowska, B., Bak, M. Handbook on Estimation of External Costs in the Transport Sector. Technical Report. CE Delft and INFRAS, Delft, The Netherlands, 2008

39. Brons, M., Christidis, P. External Cost Calculator for Marco Polo Freight Transport Project Proposals. Technical Report. Institute for Prospective and Technological Studies, Joint Research Centre,2012

40. Liu,S.D.World Rare Earth Resources Supply in 2018. Rare earth Information,2019,01:26 28

41. Tone,K.A slacks-based measure of efficiency in data envelopment analysis. European Journal of Operational Research, 2001,130:498 509 